\begin{tabular}{|l|l|l||}
\hline \multicolumn{2}{|c|}{ PublisherInfo } \\
\hline \hline PublisherName & $:$ & BioMed Central \\
\hline \hline PublisherLocation & $:$ & London \\
\hline \hline PublisherImprintName & $:$ & BioMed Central \\
\hline \hline
\end{tabular}

\title{
Europe had ten Adams
}

\begin{tabular}{|l|l|l||}
\hline \multicolumn{2}{|c|}{ ArticleInfo } \\
\hline \hline ArticleID & $:$ & 3830 \\
\hline \hline ArticleDOI & $:$ & $10.1186 /$ gb-spotlight-20001115-01 \\
\hline \hline ArticleCitationID & $:$ & spotlight-20001115-01 \\
\hline \hline ArticleSequenceNumber & $:$ & 267 \\
\hline \hline ArticleCategory & $:$ & Research news \\
\hline ArticleFirstPage & $:$ & 1 \\
\hline \hline ArticleLastPage & $:$ & 2 \\
\hline \hline & & RegistrationDate : 2000-11-15 \\
ArticleHistory & $:$ & OnlineDate $\quad 2000-11-15$ \\
\hline \hline ArticleCopyright & $:$ & BioMed Central Ltd2000 \\
\hline \hline ArticleGrants & $:$ & \\
\hline \hline ArticleContext & $:$ & 130591111 \\
\hline \hline
\end{tabular}




\section{William Wells}

Email: wells@biotext.com

In the 10 November Science Semino et al. use haplotypes from the non-recombining portion of the $\mathrm{Y}$ chromosome (NRY) of 1007 individuals to determine that ten lineages can account for $95 \%$ of European Y chromosomes (Science 2000, 290:1151-1155). Based on the geographic distribution of the haplotypes, and their age (estimated using the variation of associated microsatellites), Semino et al. identify two major haplotypes as belonging to Paleolithic peoples who migrated from the Iberian peninsula and the present Ukraine following the Last Glacial Maximum. (During this glacial period humans were forced to vacate most of central Europe.) Most of the other haplotypes are derived from Neolithic peoples who migrated from the Middle East.

\section{References}

1. Science, [http://www.sciencemag.org/]

2. Y chromosome sequence variation and the history of human populations.

This PDF file was created after publication. 